\title{
Dependence of fluid flow on cleat aperture distribution and aperture-length scaling: a case study from Gondwana coal seams of Raniganj Formation, Eastern India
}

\author{
Krishanu Bandyopadhyay $^{1} \cdot$ Jyotirmoy Mallik $^{1}$ (1) Trishit Ghosh $^{2}$
}

Received: 9 June 2019/Revised: 12 September 2019/Accepted: 14 December 2019/Published online: 31 December 2019

(C) The Author(s) 2019

\begin{abstract}
Dimensions and mutual relationships amongst fracture (cleat) parameters such as maximum aperture width, average aperture width, length, spacing etc. control the connectivity within a fracture network and the fluid flow in a coal seam as the matrix permeability, here, is negligible. In this paper, we document cleat size distributions and investigate lengthaperture relationships from coals of Raniganj coalfield in Eastern India. This coalfield has a proven extractable reserve of six billion tons of coal and holds immense potential to be one of the largest coal bed methane fields serving India's growing energy needs. Here, cleat length $(L)$ correlates with corresponding maximum aperture width $\left(D_{\max }\right)$ in a power-law function with an exponent of $0.84\left(D_{\max } \propto L^{0.84}\right)$ instead of the commonly observed exponents of 1 or 0.5 applicable for other natural 'opening-mode' fractures. The conventional wisdom pertains that laminar fluid flow $(Q)$ through an isolated, smooth-walled, parallel-plate fracture, embedded in an impermeable matrix, is directly proportional to the cube of its aperture width ( $b$, equivalent to $D_{\text {avg }}$; cubic law: $Q \propto b^{3}$ ). This assumes a linear relationship between length and fracture aperture. However, the modified relationship between cleat length and average aperture width changes the cubic law applicable for Raniganj coal seam and now fluid flow correlates with aperture width in a power-law function with an exponent of $4.25\left(Q \alpha b^{4.25}\right)$ instead of 3 (cube). Such simplifications will come handy for the modeling and estimation of fluid flow as it will reduce the effort of cleat length measurement which is anyway difficult and can be misleading due to the risk of undersampling.
\end{abstract}

Keywords CBM $\cdot$ Cleat $\cdot$ Coal $\cdot$ Permeability $\cdot$ Raniganj

$\begin{array}{ll}\text { List of symbols } \\ L & \text { Fracture length } \\ \mathrm{b} & \text { Constant aperture width } \\ D_{\text {avg }} & \text { Average aperture width } \\ Q & \text { Total laminar fluid flow } \\ D_{\max } & \text { Maximum aperture width } \\ E & \text { Young's modulus } \\ v & \text { Poisson's ratio } \\ \Delta \sigma i & \text { Driving stress } \\ \rho & \text { Fluid density } \\ g & \text { Gravitational acceleration }\end{array}$

Jyotirmoy Mallik

jmallik@iiserb.ac.in

1 Indian Institute of Science Education and Research, Bhopal, India

2 Coal India Limited, Asansol, India $\delta h \quad$ Pressure gradient

$\mu \quad$ Viscosity

$V M \quad$ Volatile matter (\%)

VRo Vitrinite reflectance

b Variations in cleat aperture from the isotropic strain line

$\varepsilon \quad$ Strain along a scanline

$R \quad$ Correlation coefficient

$K_{i} \quad$ Stress intensity factor

$K_{i c} \quad$ Fracture toughness

$\Delta \sigma i c \quad$ Critical driving stress

$n \quad$ Power law exponent in aperture-length scaling relationship

c Pre exponential constant in aperture-length scaling relationship 


\section{Introduction}

Cleats are naturally occuring primary fractures in coal seams (Kendall and Briggs 1933; Laubach et al. 1998). They are the principal pathways for the flow of free fluids (Li et al. 2011). Cleats form orthogonal to the bedding plane and generally occur as two mutually perpendicular sets (Fig. 1) namely face cleats and butt cleats. Face cleats are more prominent, regular, through-going sets of fractures which initially formed during the coalification process. The weakly developed (Kulander and Dean 1993; Laubach and Tremain 1991; Laubach et al. 1998) butt cleats form later and usually terminate orthogonally against face cleats (Ammosov and Eremin 1963; Busse et al. 2017; Close 1993; Gamson et al. 1993; Laubach et al. 1998; Ting 1977; Tremain et al. 1991). Banded or humic coals are charecterised by alternate bright and dull bands resulting variations in mechanical and fracture stratigraphy (Laubach et al. 2009). Development of cleats is restricted mostly within vitrinite rich bright bands. In some cases, few 'master cleats', cut across all the bands and can act as through-going conduits (Laubach and Tremain 1991; Laubach et al. 1998). Cleats may be partially or completely filled with secondary minerals such as pyrite, quartz, calcite, galena, marcasite, sphalerite, kaolinite, etc. (Spears and Caswell 1986). Such infilling can reduce the available aperture width for fluid flow.

In recent times, with an increase in coal bed methane $(\mathrm{CBM})$ extraction and growing interests of $\mathrm{CO}_{2}$ sequestration within coal beds, the study of cleats is gaining impetus. This recent surge has helped the community with a better understanding of cleat origin, its dimensions and classification. Laubach et al. (1998) demonstrated that coal bed permeability is largely dependent on different physical parameters such as size, spacing, connectedness, aperture, cement infill, and orientation. Their role in defining the

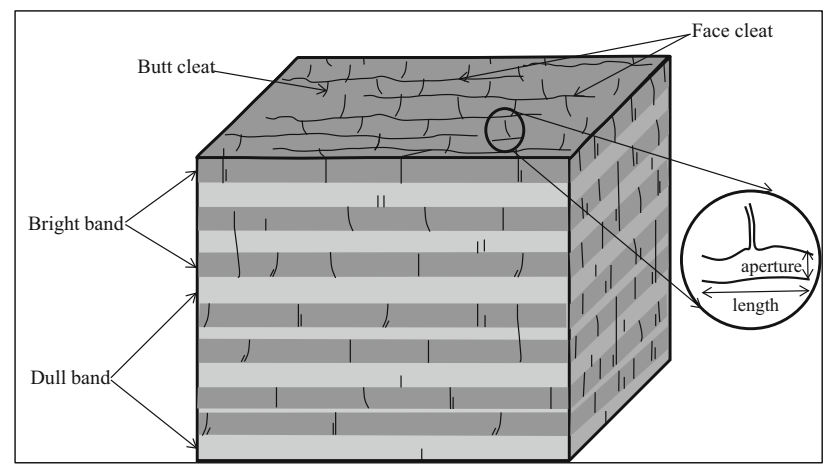

Fig. 1 Schematic diagram of bright bands, dull bands, face cleats and butt cleats (figure not to scale) in a typical banded coal sample (modified after Laubach et al. 1998). The figure contains 'primary', 'secondary', 'tertiary' and 'master cleats'. In this analysis, the length, spacing, and apertures are measured from all of these cleat types fluid flow during CBM extraction (Harpalani 1999; Palmer 2009; Reid et al. 1992; Sparks et al. 1995) and controlling the stability of the coal seams during mining operations are already recognized (Pattison et al. 1996). From the study of coal core samples of the San Juan and Warrior Basin, Puri et al. (1991) showed that Darcy flow dominates in the cleat system and contribution from coal matrix in fluid flow can be neglected. Paul and Chatterjee (2011) documented that the face and butt cleat orientations in the Jharia coalfield (adjacent to our study area) can be directly related to the observed directional permeability.

Assessing the correct permeability, in a pre-drill/pre-development stage of a CBM project, is challenging. Often the measured permeability from the cores in a laboratory is far from the observed permeability during CBM production. To close this gap, researchers are redefining coal permeability estimations based on fracture models [e.g. Discrete Fracture Network models described in Liu et al. (2019), Zhang et al. (2015), Zhi et al. (2018)]. Equating fracture parameters with resultant permeability requires certain analytical solutions like the 'cubic law' (details in Sect. 2). Attempts were made to simplify the cubic law by reducing the number of measurable input parameters by establishing mutual relationships between them (For example, cubic law can be simplified to quintic law where fluid flow is a function of only fracture aperture; Klimczak et al. 2010).

The geology of Ranigunj coalfield is relatively well studied (Chakraborty et al. 2003; Ghosh 2002; Paul and Chatterjee 2011; Prusty et al. 2015; Vishal and Singh 2015). However, characterization of cleats and understanding its control on permeability, prior to any significant CBM exploition, demands attention. In this paper, we have discussed aperture-size distribution of coal cleats from Raniganj coals and have quantified the relevant scaling relationship between cleat length and aperture. Results are then compared with the same from other types of tensile fractures hosted in igneous, sedimentary and metamorphic rocks as well as with theoretical solutions. We demonstrated that the 'cubic law' correlating fracture aperture and permeability can be further simplified here, leading to a less ambiguous analytical solution of coal permeability.

\section{Background}

\subsection{Application of fracture mechanics in the study of natural rocks}

One of the key aspects of fracture mechanics is to establish displacement-length relationships for different kinds of naturally forming fractures such as dykes, veins, joints, faults, deformation bands and shear bands (Aydin et al. 2006; Clark and Cox 1996; Cowie and Scholz 1992a; Lawn 
1993; Scholz 2002; Schultz et al. 2008a; Vermilye and Scholz 1995; Xu et al. 2005). In such studies, "Linear Elastic Fracture Model (LEFM)" is applied with the assumption that the host rock is homogeneous and isotropic. The governing equation used to construct LEFM models for opening mode fractures under plane strain conditions (Pollard and Segall 1987) is based on a linear relationship between fracture length $(L)$ and maximum displacement $\left(D_{\max }\right.$, equivalent to maximum aperture width) measured perpendicular to the fracture walls (Fig. 2). It is expressed as:

$D_{\max }=\Delta \sigma i 2 L\left(1-v^{2}\right) / E$

where $v$ is the Poisson's ratio and $E$ is the Young's modulus of the host rock. This correlation is consistent when the fractures are noninteracting and growing under conditions of constant driving stress $\Delta \sigma i$ (Scholz 2002).

Traditionally, the total laminar fluid flow $(Q)$ through fractures which are assumed to be an open space between two smooth parallel plates (Boussinesq 1868; Klimczak et al. 2010; Snow 1965) with a constant width $(b)$ perpendicular to the direction of flow (Fig. 2) is estimated to be proportional to the cube of ' $b$ '. This relationship between $Q$ and $b$ is known as the 'cubic law' (Klimczak et al. 2010; Krantz et al. 1979; Lomize 1961; Louis 1969; Snow 1965; Tsang and Witherspoon 1981) and expressed by the equation:

$Q=-\rho g b^{3} \delta h L /(12 \mu)$

where $\rho$ is fluid density, $g$ is gravitational acceleration, $\delta h$ is pressure gradient, $\mu$ is viscosity of the fluid and $L$ is plate length, equivalent to fracture length.

It is already recognized that the cleat attributes resemble those of opening mode fractures in other types of rocks
(Campbell 1979; Dron 1925; Kendall and Briggs 1933; Laubach et al. 1998; McCulloch et al. 1974, 1976; Ting 1977; Williamson 1967). Due to the lack of appreciable wall parallel shear offset, cleats are considered as typical opening-mode fractures (Laubach et al. 1998). Hence, it is plausible to argue that LEFM is applicable to coal cleats.

\subsection{Study area}

The study area is located at the Raniganj coalfield (in and around the city of Asansol) in the states of West Bengal and Jharkhand, India (Fig. 3). This coalfield marks the eastern end of the chain of Eastern Indian Coalfields. In terms of reserves, it is the second-largest coalfield of India with a proven extractable reserve of six billion tons of coal (http://bardhaman.nic.in/mines/mines.htm).

The coal seams of the Raniganj basin were deposited in two Formations: (1) stratigraphically older early Permian Barakar Formation and (2) younger, late Permian Raniganj Formation. They are separated by the non-coaly Barren measure Formation. The facies changes are gradational. The elongated Raniganj basin extends $\sim 70 \mathrm{~km}$ in WNWESE direction having an width of $\sim 20 \mathrm{~km}$ (Chakraborty et al. 2003). The basin's northern boundary is demarcated by a WNW-ESE trending fault zone. The southern boundary is marked by several faults parallel/subparallel to the northern boundary faults. The western limit of the basin is defined by two major faults; one of which strikes along NW-SE and the other strikes along NNE-SSW. Two sets of intra-basinal, normal faults are present throughout the basin. They strike in NNW-SSE and NNE-SSW directions. The general southerly dip of the coal-bearing Raniganj and Barakar measures is low $\left(\sim 5^{\circ}\right)$ to moderate $\left(\right.$ rarely $\left.>10^{\circ}\right)$.

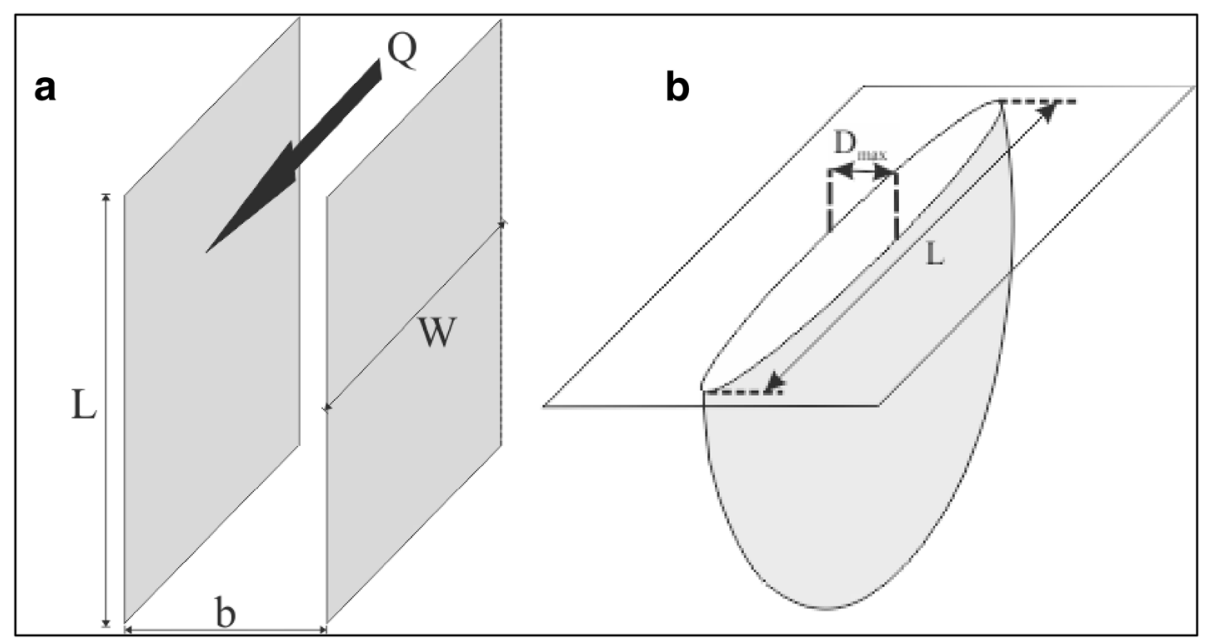

Fig. 2 a Schematic diagram (modified after Klimczak et al. 2010) of fluid flow $(Q)$ through parallel plates with length $L$, breadth $W$, and constant aperture width $b$. ' $b$ ' is equivalent to $D_{a v g}$. b Schematic diagram of an ideal isolated fracture with an elliptical opening profile having Length $L$ and maximum aperture width $D_{\max }$ 


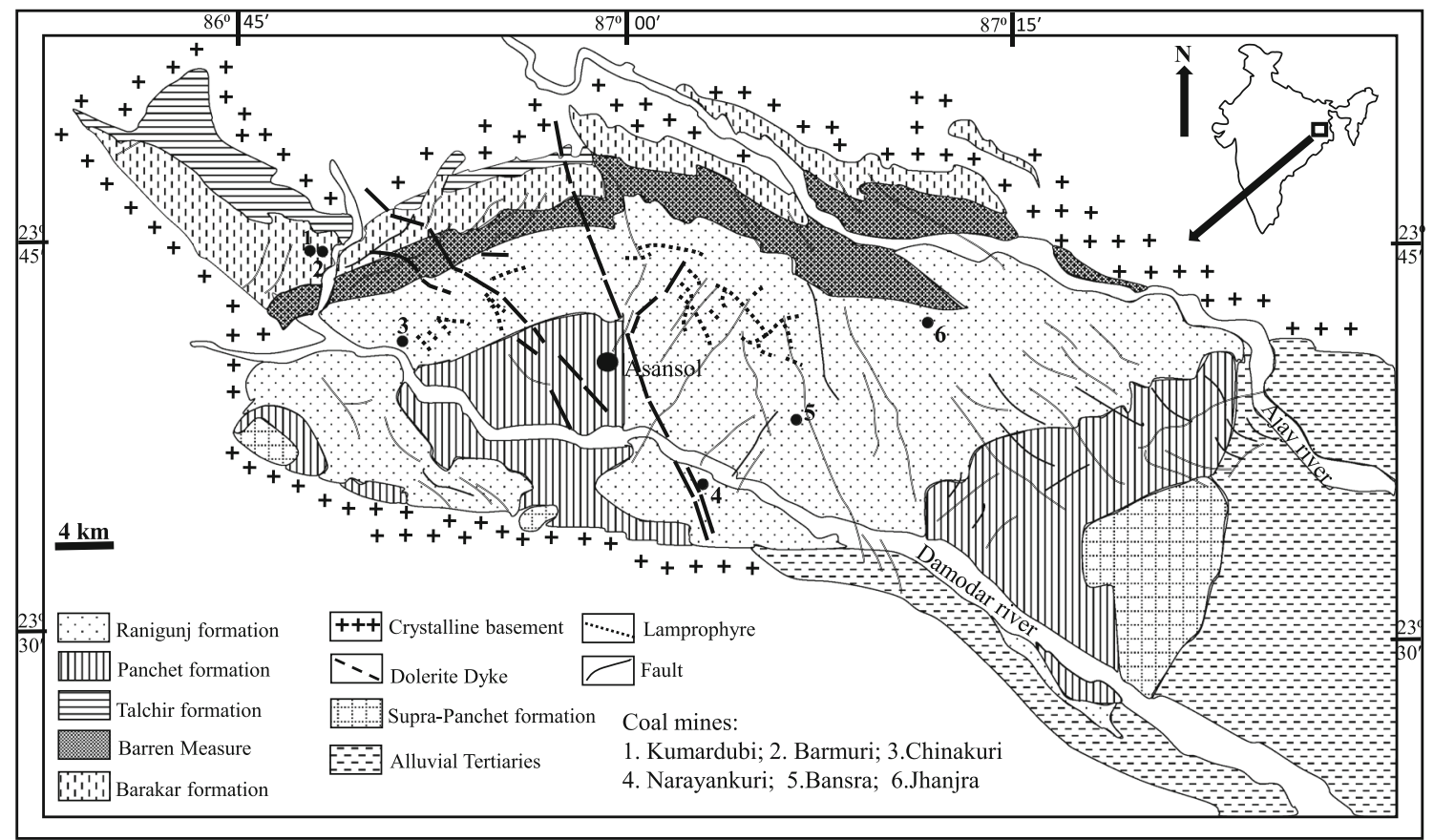

Fig. 3 Location and simplified geological structure of the study area showing different geological Formations and faults associated with the Raniganj basin (modified after Gupta 2009). The numbered black dots represent the sampling locations. The samples selected for this study are obtained from Chinakuri, Narayankuri, Jhanjra, and Bansra coal mines

\section{Methodology}

\subsection{Sampling}

Multiple blocks (Fig. 4) of bituminous to sub-bituminous ranked coals were collected from three underground mines (Chinakuri, Bansra, and Jhanjra) and one opencast mine (Narayankuri). Sampling covered multiple sub-seams (Table 1) of the Raniganj Formation spreading over a wide depth range $(0-613 \mathrm{~m})$. The average sample size is $\sim 6 \times 6 \times 6$ cubic $\mathrm{cm}$. Emphasis was given to collect some samples from recognizable fault zones to understand the effect of deformation on cleat development and preservation.

The moisture, ash, volatile matter and fixed carbon data are collected from the internal reports of Coal India Limited. The vitrinite reflectance $(V R o)$ is derived from a modified empirical equation https://shodhganga.inflibnet. ac.in/bitstream/10603/32892/13/13_chapter\%203.pdf: $V R o \%=(49.90-V M \%) / 18.98$.

\subsection{Measurement of aperture and length}

Quantification of the physical attributes of cleat network can be challenging. In literature, different methods were prescribed for visual estimation of cleat attributes. Geographic Information System (GIS) derived data were used to determine regional cleat orientation and spatial cleat network (Rodrigues et al. 2014). In an outcrop scale, usually, a magnifying glass with a ruler or a comparator are used to measure cleat parameters (Dawson and Esterle 2010; Ortega et al. 2006; Paul and Chatterjee 2011). Borehole logging data are also used as a guide in measuring cleat attributes under in situ stress condition (Chatterjee and Paul 2013; Close and Mavor 1991). These methods have a resolution limit up to the millimeter scale (Dawson and Esterle 2010; Gale et al. 2007; Hooker et al. 2009). Hence, quantifying cleat attributes under different microscopes is a common practice to determine cleat length, aperture, spacing, etc. Mazumder et al. (2006) used $\mathrm{X}$-ray computed tomography images to analyze cleat spacing and aperture distribution. They introduced the term 'relevant cleat length' to express cleat length as a function of measured spacing.

In order to overcome these challenges and to avoid biases originating from different scales of measurements, it is generally agreed to collect the cleat/fracture attribute data by three standard techniques: (a) measurement along circular scanlines, (b) two-dimensional (2D) box-counting and (c) along one-dimensional straight scanlines. In case of steeply dipping multiple fracture sets, orientation-bias free circular scanlines may be used (Mauldon et al. 2001; Rohrbaugh and Dunne Mauldon 2002). The 2D boxcounting method has several advantages like this method is suitable for a scattered dataset and it provides more accuracy as the trigonometric measurement corrections are not 


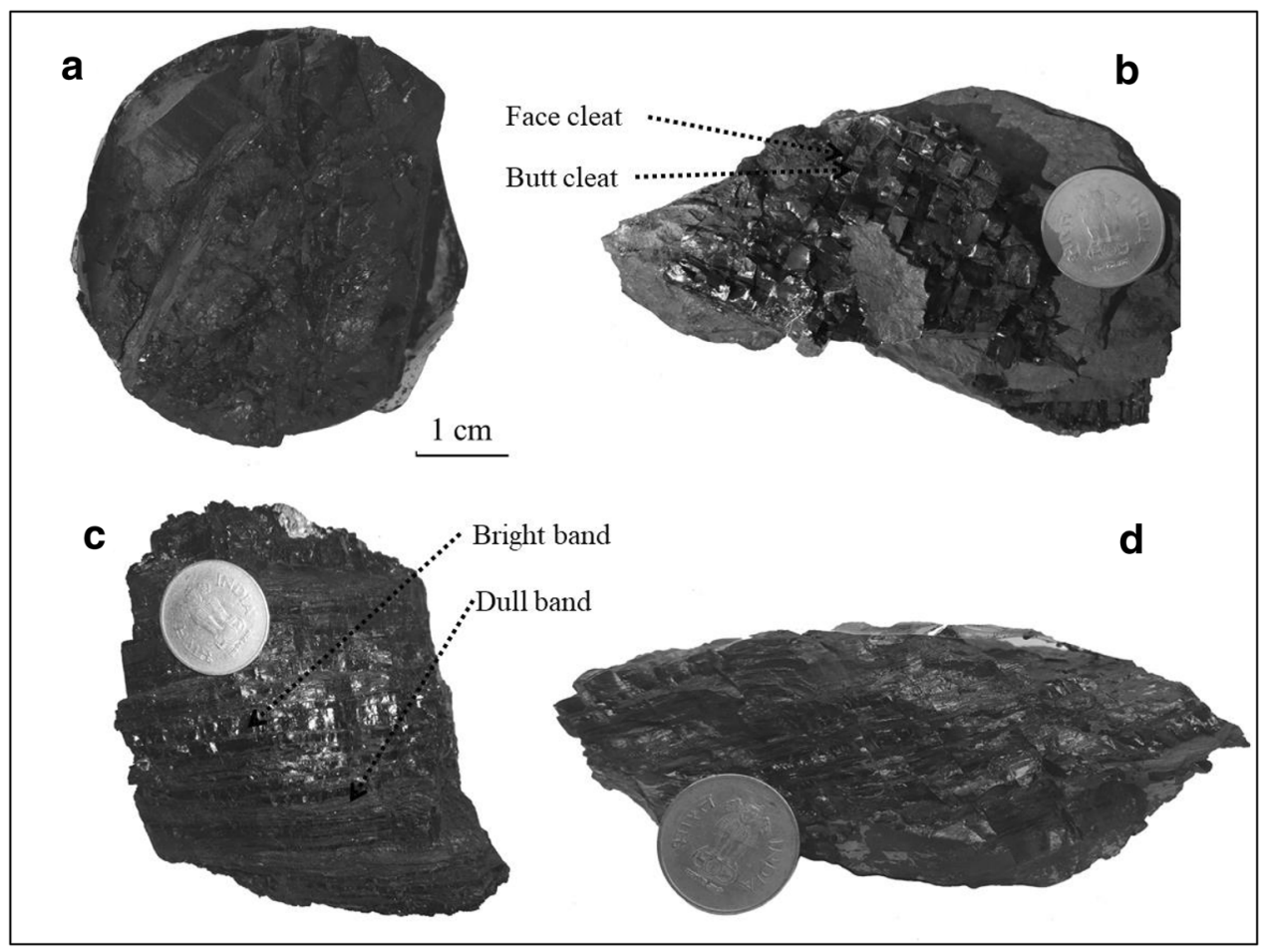

Fig. 4 Coal samples collected from the study area with $\mathbf{a}, \mathbf{b}$ different intensities of cleat formation; $\mathbf{c}, \mathbf{d}$ alternate bright bands and dull bands in coal samples

Table 1 Summary of the proximate analysis report of the collected samples from multiple seams at different depths

\begin{tabular}{|c|c|c|c|c|c|c|c|}
\hline \multirow{2}{*}{$\begin{array}{l}\text { Mine/block name } \\
\text { Fixed carbon }(\%)\end{array}$} & \multirow[t]{2}{*}{ Seam } & \multicolumn{3}{|c|}{ Depth (m) } & \multirow[t]{2}{*}{ Moisture (\%) } & \multirow[t]{2}{*}{ Ash (\%) } & \multirow{2}{*}{$\begin{array}{l}\text { Volatile matter } \\
(\%)\end{array}$} \\
\hline & & $\begin{array}{l}\text { Derived } \\
\text { VRo }(\%)\end{array}$ & & & & & \\
\hline Chinakuri & $\mathrm{R} 4$ & 613 & 1.8 & 15.8 & 34.4 & 48 & 0.82 \\
\hline Narayankuri & $\mathrm{R} 8 \mathrm{~B}$ & 25 & 5.9 & 24.3 & 29.3 & 41.1 & 1.09 \\
\hline Bansra & R8B & $35-197$ & 6.4 & 23.5 & 29.3 & 40.7 & 1.09 \\
\hline \multirow[t]{3}{*}{ Jhanjra } & R7A & 65 & 7.8 & 23.2 & 29 & 39.9 & 1.10 \\
\hline & R7 & 65 & 7.7 & 28.8 & 27.2 & 36.5 & 1.20 \\
\hline & R6 & $97-157$ & 6.4 & 20.5 & 30.2 & 41.7 & 1.04 \\
\hline
\end{tabular}

required when fracture sets are oriented along multiple strike lines. The 2D box-counting method also comes with certain limitations like it is very time consuming (Gillespie et al. 1993) and can be subjective due to the complicated nature of the fracture networks in some cases. Nevertheless, measurement of cleat attributes along 1-D scanlines is popular amongst researchers (Apriyani et al. 2014; Hooker et al. 2009; Marrett et al. 1999; Ortega et al. 2006; Sapiie et al. 2014; Solano-Acosta et al. 2007; Weniger et al. 2016) due to several reasons: (1) it is a relatively quick and straightforward technique as trigonometric corrections are not required for single/two sets of parallel fractures; (2) multiple related attributes, such as spacing, aperture, etc. can be measured together; (3) the technique is independent of the scale of measurement and of rock-types that facilitates comparison between similar dataset from different lithologies of varied scales.

In the current study, multiple polished chips (from both bright and dull bands) were cut parallel to the bedding plane of each sample and were observed under Reflected light optical microscope and scanning electron microscope (Fig. 5). The samples were imaged at magnifications of $5 \times 10$ and $10 \times 10$ using a Leica DM750P microscope mounted with a LeicaEC4 camera. The images were acquired and measurements were carried out with a software named Leica Application suite version 3.4.0. LAS EZ.

We applied the 1D scanline method for cleat aperture measurement by placing multiple scanlines orthogonal to the direction of face or butt cleats. Each scanline starts at 

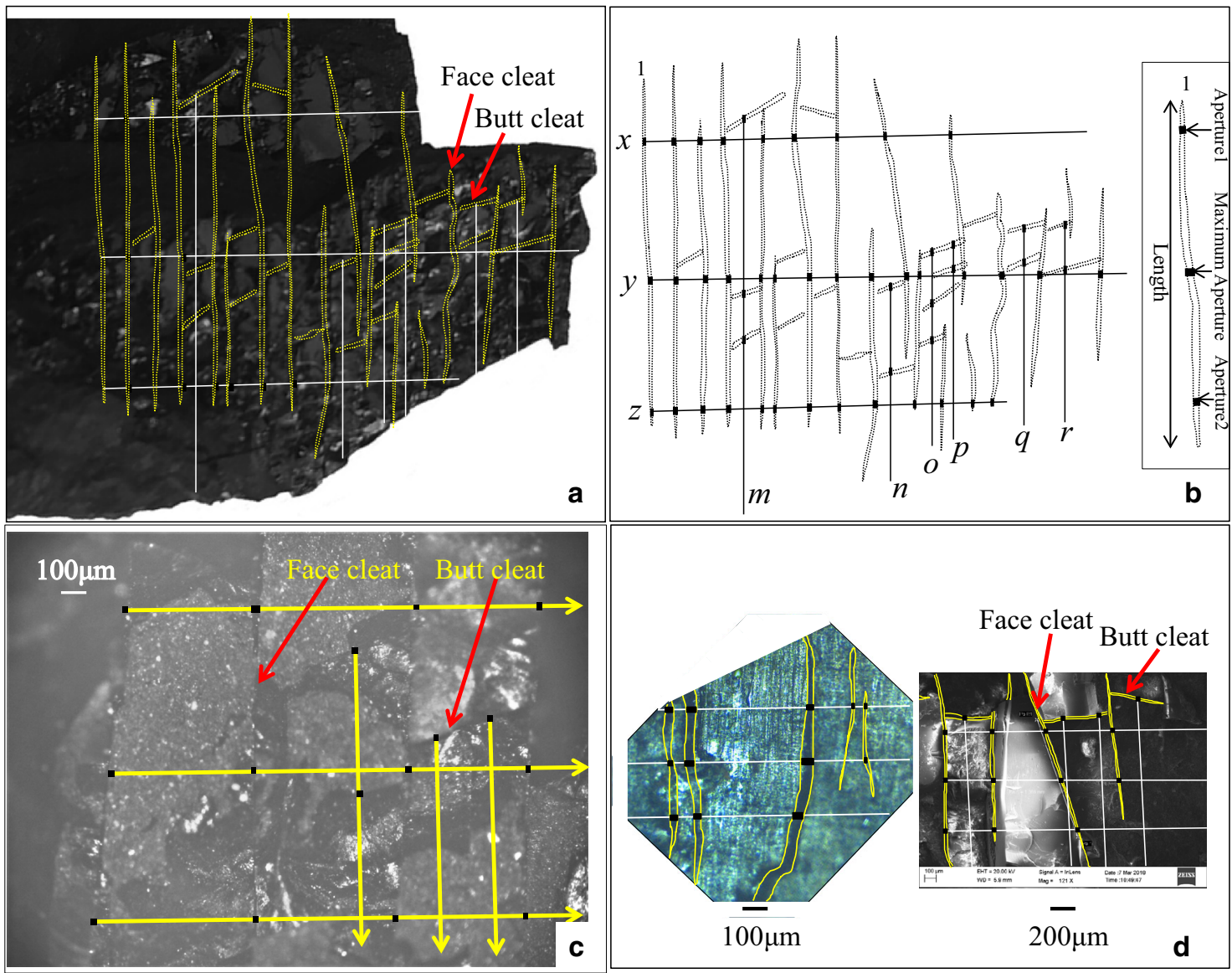

Fig. 5 Images of cleats from a a hand specimen chip from Narayankuri with superposed scanlines; b schematic cleat scanline (1D) diagram traced from (a) showing measurement methodology of cleat aperture and length. Inset showing an example: 'cleat 1' intersects the three scanlines $x, y$ and $z$ at three locations. Mean of aperture measurements at these three locations represent the average aperture of cleat 1 and largest of them is $D_{\max } ; \mathbf{c}, \mathbf{d}$ same as (b) under optical microscope and scanning electron microscope (SEM)

the first cleat subject to measurement. We define the aperture width of a cleat as the distance measured along the scanline between its two opposite fracture walls. Maximum opening displacement along the fracture length is coined as maximum aperture width $\left(D_{\max }\right)$. Generally, each cleat is encountered by more than one scanline providing multiple width measurements on a single cleat. The arithmetic mean of such multiple measured apertures represents the average aperture width $\left(D_{\text {avg }}\right)$ of that cleat (Fig. 5). This technique is consistent with the approach established by Oron and Berkowitz (1998) who demonstrated that the aperture applicable in 'cubic-law' should be measured as an average over a certain length of the fracture. From each sample, approximately sixteen to thirty aperture measurements were carried out. As the aim of this study is to understand the relationship between cleat length and aperture and use that correlation to estimate the cumulative fluid flow, we included all cleat types (primary, secondary, tertiary and master cleats) independent of their corresponding mechanical or fracture stratigraphy (Dawson and Esterle 2010; Pattison et al. 1996).

The measurement of the cleat aperture has its inherent limitations. Due to the irregular nature of their boundaries, it is often difficult to distinguish the infilling of secondary minerals,coal fragments. This issue is minimized by proper selection of cleats under Scanning Electron Microscope (SEM) and by measuring the effective aperture width (or hydraulic aperture).

The length $(L)$ of a cleat is the distance measured along a straight line joining the two tips of it on a bedding parallel plane. Cleat lengths were measured in hand specimen and under a microscope. When both tips of the cleat are visible, the measurement of its length is simple. Such measurement can be difficult when cleats are longer than the sample or the chip under a microscope. In such cases, tentative extrapolations are done assuming that the aperture varies regularly along the length, with maximum aperture in the middle and zero aperture at the tips. This is a valid assumption as cleats are typical opening mode fractures. 

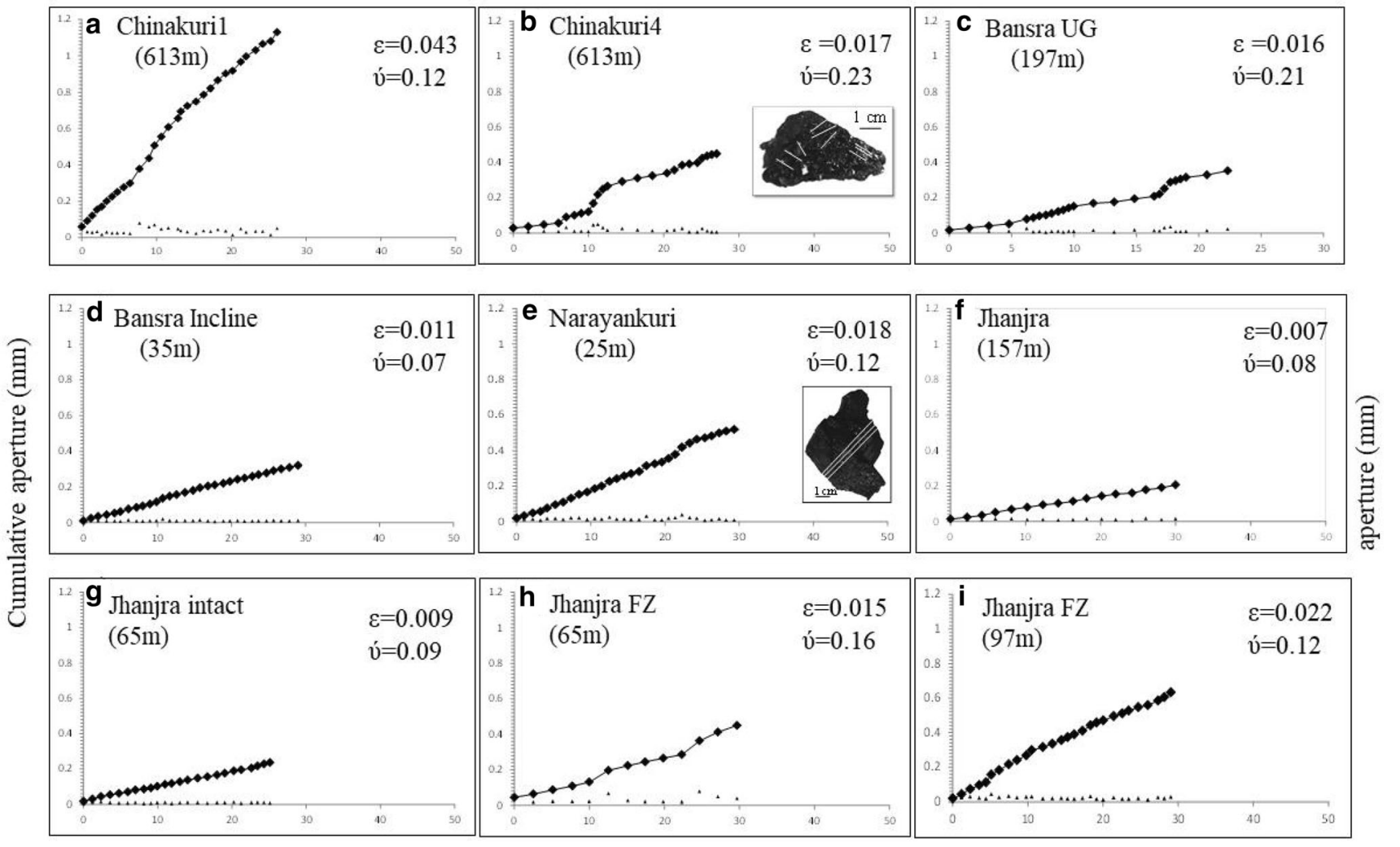

Distance along scanline $(\mathrm{mm})$

Fig. 6 Cumulative cleat aperture along scanlines from one sample of each of the four locations as outlined in Fig. 3. The solid rectangles on these plots show the cumulative frequencies and the solid triangles represent individual aperture measurements. Sampling depths, the strain ( $\varepsilon$ ) and variability $(b)$ along the scanline are labelled on each plot suggesting the effect of faults (FZ: sample collected within $1 \mathrm{~m}$ of fault zone) is more on the variability than their depth of occurrence and strain. The inset figures in (b) and (e) are examples of highly variable and almost uniform cleat patterns respectively

Presence of at least one tip in the microscopic view or in the sample reduces measurement related uncertainties.

Numerous definitions of cleats based on their sizes are common in literature such as micro cleats, macro cleats, mega cleats, etc. An uniform classification based on cleat size is not well established. It is important to state that we are only considering 'sensu stricto' cleats that are of micro to millimeter-scale in length and forms the primary fracture network in coal during desiccation. Larger secondary coal fractures (could be even traceable across adjacent boreholes) formed during exhumation or deformation are excluded from our current study and their interaction with the cleat system needs further investigations.

\section{Results}

\subsection{Aperture size and distribution}

The smallest aperture in the entire sample population is observed to be about $5 \mu \mathrm{m}$ whereas the largest one is about
$80 \mu \mathrm{m}$. Such a wide range in aperture is possibly due to large variation in sampling depth and non-uniform macerals. Average aperture varies between 12 and $49 \mu \mathrm{m}$. The samples from Jhanjra have the most prominently developed and easily distinguishable face and butt cleats. On the contrary, the samples from Chinakuri mines show a complex network of the cleat orientations where the face and butt cleats are almost indistinguishable. Coal samples from these two mines (Jhanjra and Chinakuri) show relatively wider ranges in measured average apertures $(20-49 \mu \mathrm{m})$. The associated variation in measured aperture along a scanline (Fig. 6) is quantified by a numerical parameter (b) which is the ratio of the sum of absolute maximum and minimum variations in cleat aperture from the isotropic strain line with the cumulative aperture (Brook et al. 2016). The isotropic strain line, connecting the origin to the final cumulative aperture in each plot (Fig. 6), represents a line of homogeneous strain. The samples collected from undisturbed seams of Bansra (incline mine) and Jhanjra coal mines show uniformly distributed aperture size and spacing resulting lower values of $b(0.07-0.09)$. The value 
of $b$ is relatively larger $(0.12-0.23)$ in the samples collected near the faults from Chinakuri, Bansra, and Jhanjra mines. The strain ( $\varepsilon$ ) along the scanline (Fig. 6), obtained from the ratio of the sum of the apertures to the scanline length (Brook et al. 2016), varies between 0.007 (Jhanjra coal sample) to 0.043 (Chinakuri coal sample).

\subsection{The relationship between cleat length and aperture}

Figure 7 shows robust linear correlation $\left(R^{2}=0.89\right)$ between average aperture $\left(D_{a v g}\right)$ and maximum aperture $\left(D_{\max }\right)$ of individual cleats from different samples. The regression line is set to intercept the origin as $D_{\max }$ should be zero when $D_{\text {avg }}$ is zero. Rounding off the slope of the regression line to 1.6 , we can formulate a simple empirical equation of $D_{\max }$ as a function of $D_{a v g}$ as:

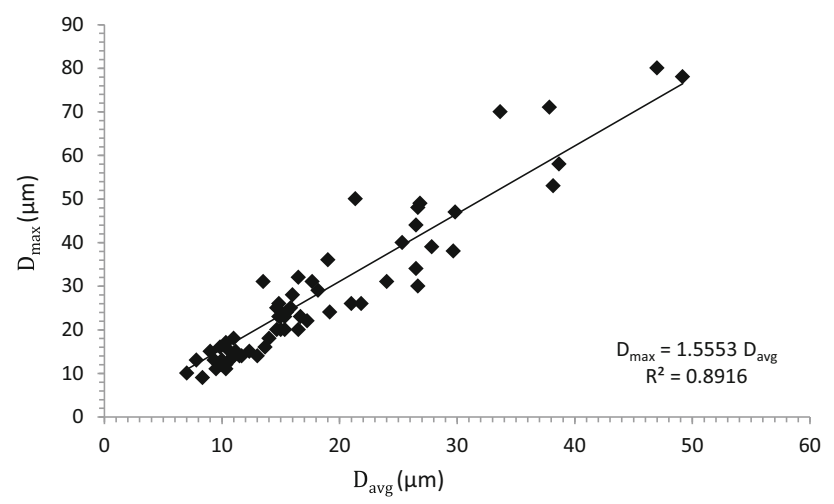

Fig. 7 The plot of average aperture width $\left(D_{\text {avg }}\right)$ versus maximum aperture width $\left(D_{\max }\right)$ for Raniganj coals showing a strong linear correlation between them

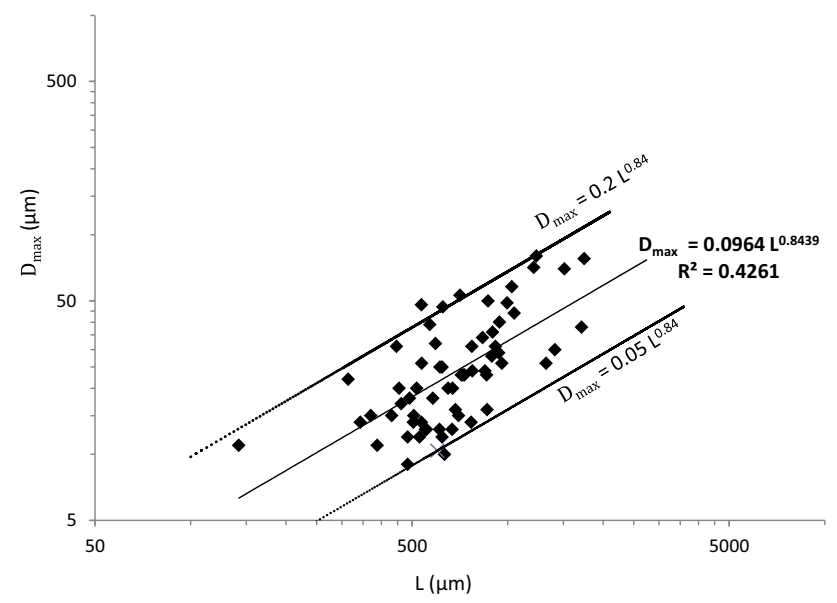

Fig. 8 The plot of cleat length $(L)$ versus maximum aperture width $\left(D_{\max }\right)$ for Raniganj coals with a power-law best fit trend captured by the continuous black straight line. The upper and lower dotted trend lines capture the spread of the measured data
$D_{\max }=1.6 D_{\text {avg }}$

The mutual relationship between maximum aperture $\left(D_{\text {max }}\right)$ and cleat length $(L)$ obeys a power-law distribution (Fig. 8). The correlation is expressed as:

$D_{\max }=0.1 L^{0.84}$

Combining Eqs. (3) and (4) and substituting $D_{\max }$ with $D_{a v g}$, the equation correlating $L$ and $D_{a v g}$ (power-law exponent is rounded off to 0.8 ) can be expressed as:

$L=\left(16 D_{\text {avg }}\right)^{1 / 0.8}$

\subsection{Calibration of the 'cubic law'}

We can estimate the potential fluid flow through the cleats by applying 'cubic law' as shown in Eq. (2).

Using Eq. (2), if fracture length $(L)$ is substituted with $D_{\text {avg }}$ (' $b$ ' in cubic law), the equation can be written as:

$Q=-\left\{\left(\rho g b^{3} \delta h\right) / 12 \mu\right\} *\left\{(16 b)^{\frac{1}{0.8}}\right\}$

Equation (6) can be further simplified as:

$Q=-\left(8 \rho g b^{4.25} \delta h\right) / 3 \mu$

Equation (7) suggests that the flow-rate through the measured cleats is proportional to the aperture with a power exponent of 4.25 .

\section{Discussion}

\subsection{Comparison of cleat dimensions with global studies}

Compared to joints, veins, dikes and other opening-mode fractures in different host rocks, the aperture size for coal cleats is of at least one order of lower magnitude (Fig. 9). However, the measured dimensions (aperture 5-80 $\mu \mathrm{m}$ ) of cleats from Ranigunj field lie within the known range of cleat dimensions measured from other coaliferous basins around the world. Tremain et al. (1991) reported cleat heights and lengths to vary from microns to meters in Fruitland Formation of San Juan Basin, New Mexico. Close and Mavor (1991) analyzed drilled coal cores from the San Juan Basin and reported apertures varying from 0.01 to $0.2 \mathrm{~mm}$. From parallel-plate fracture permeability models, Laubach et al. (1998) demonstrated that cleat apertures should typically vary between 3 and $40 \mu \mathrm{m}$. Weniger et al. (2016) carried out at least 8000 individual measurements of coal cleats from several European basins and reported a median aperture of $29 \mu \mathrm{m}$ with a range in 


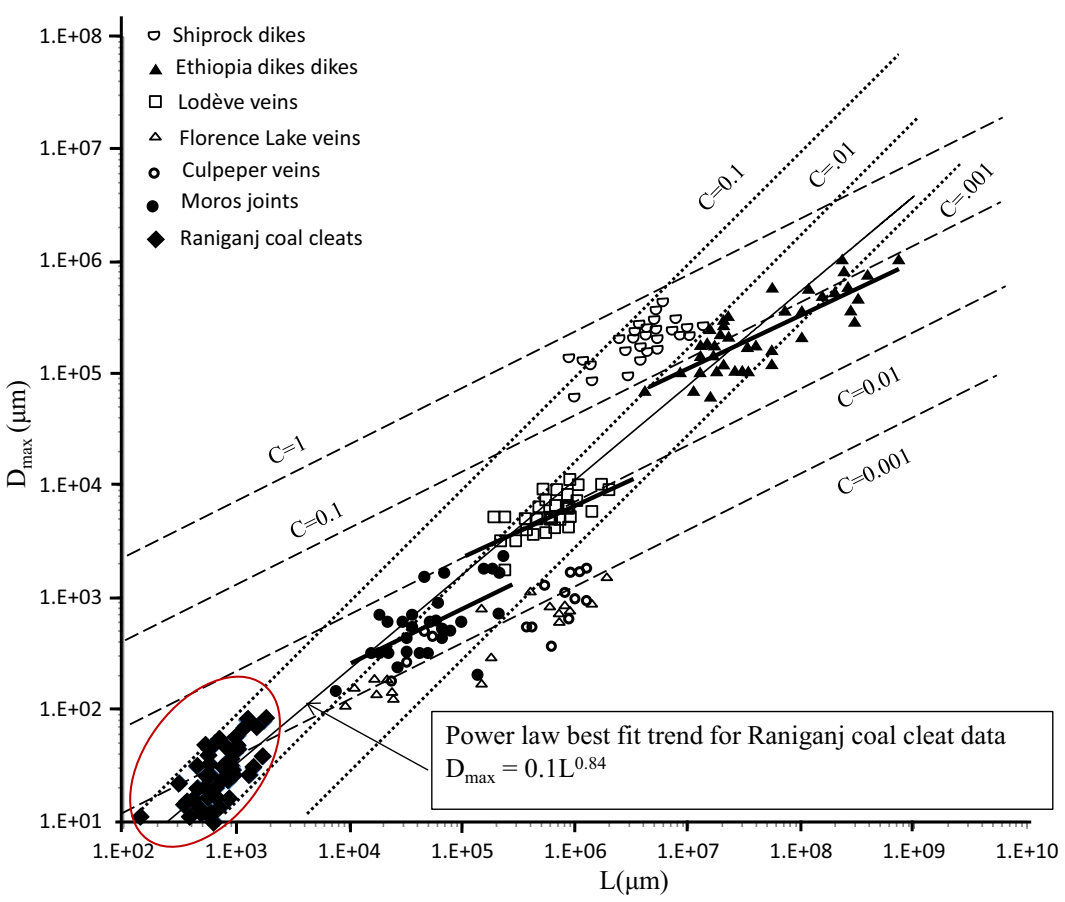

Fig. 9 Compilation of cleat length versus maximum aperture width $\left(D_{\max }\right)$ for Raniganj coals (rectangular solid dots within the encircling ellipse) with equivalent data sets for opening mode joints, veins and dikes (see: Schultz et al. 2008a, b). Dotted and dashed lines represent different slopes (pre-exponential constant ' $c$ ') with constant values of $n=1$ and $n=0.5$ respectively. Darker lines show power-law fits to: Lode've sparitic sinuous veins: $D_{\max }=0.01 L^{0.47}, R^{2}=0.41$; Moros joints: $D_{\max }=0.0025 L^{0.48}, R^{2}=0.45$; and Ethiopia dikes: $D_{\max }$ $=0.078 L^{0.49}, R^{2}=0.66$

median values between 7 and $50 \mu \mathrm{m}$, similar to the Raniganj coals.

Relatively wider cleat aperture distribution from Chinakuri and Jhanjra coal samples can be explained by the presence of small scale faults (throw $<2 \mathrm{~m}$ ). This is further manifested in the higher values of $b$ in the samples from the deformed hanging walls compared to the undisturbed footwalls. Syntectonic deposition of coals in the hanging walls of such intrabasinal faults was reported in this area by Ghosh (2002). The width of the deformation zones associated with such small faults is limited $(<2 \mathrm{~m})$ and is not expected to affect the regional fracturing pattern and therefore, the derived permeability should also remain unaffected.

However, the effect of tectonism on the development of cleat was reported from Bowen Basin, Australia (Dawson and Esterle 2010; Esterle and Sliwa 2002) where cleat orientation follows local stresses.

\subsection{Fracture length-aperture width scaling ratios: comparison with global studies}

Derived power-law function between cleat length and average aperture is consistent with the theoretical derivations and previously studied outcrop data. Schultz et al. (2008a) compiled and classified such data from various geological discontinuities into four distinct classes: (1) faults; (2) joints, veins, dikes; (3) deformation bands and (4) compaction bands. They showed that maximum aperture $\left(D_{\max }\right)$ and fracture length $(L)$ obeys a power law function except in faults where they vary linearly (Cowie and Scholz 1992a; Scholz 2002; Xu et al. 2005). Theoretically, for interacting and propagating cracks of varied lengths, the constant driving stress, as applied in Eq. (1), is insufficient (Segall 1984). Lawn and Wilshaw (1975) established that opening mode fracture propagation is dependent on stress intensity factor $\left(K_{i}\right)$ at the fracture tip. $K_{i}$ increases linearly with driving stress and with the square root of half of the fracture length (Eq. 8).

$K i=\Delta \sigma i(\pi L / 2)^{0.5}$

Olson (2003) showed that according to Griffith's criteria for energy balance, fracture propagation initiates when $K_{i}$ becomes greater than or equal to the intrinsic fracture toughness $\left(K_{i c}\right)$ of the host material.

Thus, by substituting the constant driving stress $(\Delta \sigma i)$ and stress intensity factor $\left(K_{i}\right)$ by critical driving stress $\left(\Delta \sigma_{i c}\right)$ and material specific fracture toughness $\left(K_{i c}\right)$ from Eq. (8) into Eq. (1), the modified expression at critical stage of initiation of crack propagation, is: 
$D_{\max }=c L^{n}$

where $n=0.5$ and $c$ is termed as pre-exponential constant expressed with units of length ${ }^{(1-n)}$ and described as

$c=\operatorname{Kic}\left(1-v^{2}\right) /\{E \sqrt{ }(\pi / 8)\}$

The value of the power exponent ' $n$ ' in opening mode fractures from non-coaly rocks is close to the theoretically derived value of 0.5 as predicted by Eqs. $(8,9)$, whereas the value of $n$ is 0.84 for the cleats from our study area. Figure 9 shows the comparison.

This increment in the value of the power exponent ' $n$ ' can be due to multiple reasons:

\section{(1) Interference of multiple fracture sets}

Formation of cleat network (intersection of face and butt cleats; Figs. 4, 5) is the most important reason for the enhanced ' $n$ ' value. The study of joints in Krafla fissure swarm (Hatton et al. 1994) revealed that ' $n$ ' is greater than 2 for a certain sets of joints which are partially linked. Such linking can result in accumulation of extra width than expected from theoretical analysis of simple isolated elliptical fractures. Olson (2003) also suggested that strain transfer between different joints with varying degrees of overlaps and spacings can significantly impact the scaling relationship. Similarly, the interaction of face and butt cleats causes strain transfer between them leading to the development of an integrated cleat network system. This network is a clear deviation from an ideal isolated fracture (Fig. 2b) and thus results in an enhanced value of ' $n$ ' for the studied cleat system.

(2) The mixture of hierarchical and top-bound fracture stratigraphy

Competency contrast between stratigraphic intervals and the nature of their interfaces influence the vertical dimension of structural discontinuities (Alzayer et al. 2015; Benedicto et al. 2003; Nicol et al. 1996; Schultz et al. 2008a; Soliva and Benedicto 2005; Wilkins and Gross 2002). Alzayer et al. (2015) proposed a geometric growth model (model 4, Fig. 7 in Alzayer et al. 2015) for openingmode fractures in layered sedimentary rocks where bedding interfaces constrain the fracture height. In this model, under sustained loading, fracture propagation gets arrested to a finite fracture height but continues to grow in length impacting the power-law exponent between fracture length and aperture to deviate from the ideal value of 0.5 . According to the fracture stratigraphy classification scheme proposed by Hooker et al. (2013), 'bed boundary containment' of fractures, where interbedded fracturedlayer thicknesses control fracture height, is often achieved by fracture 'hierarchy'. In banded coals, a hierarchy of subtle competency contrasts (mechanical stratigraphy) controls cleat height (Laubach et al. 1998, 2009). In Ranigunj coals, we observe sharp bedding interfaces between alternating bright and dull bands limiting the maximum cleat height to the thickness of the bright bands (vitrinite rich shiny brittle coal bands) containing them (Fig. 4). These cleats, do not follow the ideal elastic growth model constrained by their stationary tips at the bedding interfaces. Less abundant smaller cleats in the bright bands, also known as secondary and tertiary cleats, do not extend up to the bounding interfaces. They follow a linear elastic growth model where the fracture propagates concurrently in length, height and aperture (model 1, Fig. 7, Alzayer et al. 2015). As we measured all cleats encountered along the scanlines without differentiating their type, our data represents a mixture of 'hierarchical and top-bound fracture stratigraphy' (Hooker et al. 2013). Our analysis followed a holistic approach where variabilities both in loading history (indicated by fracture stratigraphy), i.e., the maturity of coals (Weniger et al. 2016) and the difference in the rock mechanical properties (mechanical stratigraphy) are incorporated. For this study, we considered this to be a reasonable approximation as mechanical stratigraphy coincides with fracture stratigraphy (Laubach et al. 2009) in banded coals.

\section{(3) Post propagation dilation}

After fracture propagation is ceased, the void spaces between fracture walls can further dilate without propagation in length due to layer parallel extension by further loading, provided that the void spaces are not filled with secondary minerals or cement. Additional dilation may also lead to an enhanced exponent value (Olson 2003). From the reconstructed opening history of tensile fractures with crack seal quartz cement bridges, Alzayer et al. (2015) observed that fracture opening increments follow the kinematics of non-linear fracture growth having distinct stages of opening viz. (a) an initial fast propagation stage succeeded by (b) a phase of slow propagation. Studies by Segall (1984) and Olson (2003) also suggest that evolution of joints can occur in two similar stages (an initial unstable propagation with $n \sim 1$ which subsequently stabilizes with a lower scaling exponent value of $\sim 0.5$ (Schultz et al. 2008a; Olson 2003). This leads to an increased data scatter with the average value of scaling exponent lying in between those two end-member values (0.5 and 1).

Variation in mechanical properties of rock such as fracture toughness, Young's modulus, Poisson's ratio has a significant influence on the displacement-length relationship (Cowie and Scholz 1992b; Gudmundsson 2004; Olson 2003; Schultz et al. 2006, 2008a). Their influence is mainly on the value of ' $c$ ' [Eq. (9)] which controls the vertical shift of the power-law fitting line. For opening mode fractures, ' $c$ ' values are reported from different lithotypes at multiple locations across the world (e.g. Ethiopia dikes: 0.078, Moros' joints: 0.0025, Lodeve veins: 0.01, Culpeper Quarry: 0.00092, Florence Lake: 0.00068 and 
Shiprock dikes: 0.43) (Fig. 9) (Delaney et al. 1986; Delaney and Pollard 1981; Olson 2003). The observed empirical value of ' $c=0.1$ ' in our study lies towards the upper bound of these reported data. Solving Eq. (9) (assuming $E \sim 0.69-6.9 \mathrm{GPa}$ and $v \sim 0.35-0.45$ ) (https://petrowiki. org/Fracture_mechanics), we computed the value of studied coal cleat $K_{i c}$ as $50-500 \mathrm{MPa} \mathrm{m}{ }^{1 / 2}$ (higher than the laboratory measured values of $K_{i c}$ from coal specimens of different locations across the world).

\subsection{Cubic law calibration for fluid flow through opening mode fractures: comparison with previous studies}

In the traditional cubic law, it is assumed that fluid flows through two smooth-walled parallel plates where the separation distance between the plates (the width ' $b$ ') remains constant along the length of the fracture. But naturally occurring isolated fractures in rocks are elliptical with the maximum aperture lying somewhere at the center and gradually decreases to zero at the tips. For such ideal elliptical fracture, Olson 2003, derived a theoretical relationship between the average aperture $\left(D_{\text {avg }}\right)$ (equivalent to ' $b$ ' of parallel plate configuration) and the maximum aperture $\left(D_{\max }\right)$ as:

$D_{\max }=\frac{4}{\pi} D_{\text {avg }}$

Klimczak et al. (2010) combined Eq. (9) with Eq. (10) and expressed the fracture length $(L)$ as a function of average aperture width $D_{\text {avg }}$ as:

$L=16\left(D_{\text {avg }}\right)^{2} /(\pi c)^{2}$

They incorporated this ideal elliptical displacement profile (Fig. 2) into the cubic law equation [Eq. (2)] and by substituting for $L$ [as expressed in Eq. (11)] they derive 'quintic law' for fluid flow through isolated, elliptical fractures as:

$Q=-4 \rho g b^{5} \delta h / 3 \mu(\pi c)^{2}$

This enhanced nonlinearity of fifth order of power exponent between fluid flow and aperture in the quintic law is an important simplification.

Equations (10-12) assume isolated, ideal elliptical fracture which follows linear elastic fracture mechanics. Most of the cleats are distorted ellipsoids or tabular in shape with uneven fracture walls and connected to each other by high angled intersections. It is apparent from the deviation of ' $n$ ' exponent in the aperture-length relationship, that the equation to express discharge through these cleats needs further modification of 'cubic' or 'quintic law'. Hence, based on the combination of theoretical assumptions and empirical findings, we propose that, the discharge, in this case, is proportional to the aperture with a power exponent of 4.25 as derived in Eq. (7).

Philip et al. (2005) concluded that permeability is more sensitive to fracture length than fracture aperture in case of poorly connected fracture network which is obviously not applicable for cleats. The effect of fracture wall roughness in defining the hydraulic and mechanical aperture is still debated. However, Klimczak et al. (2010) concluded that roughness of the fracture walls does not affect the cubic and quintic law and hence should not affect the proposed relation by the same logic.

\section{Conclusion}

(1) Length-aperture distribution of the cleats from Raniganj coal Formation shows significant nonlinearity and is different from other types of openingmode fractures. Well-developed cleat network, a mixture of fractures from different hierarchy and post-propagation dilation could be responsible for such deviation.

(2) The deviation leads to a modified equation (from cubic law) that relates fluid flow with the fracture aperture. The modified equation provides simplicity by reducing the number of variables required to calculate fluid flow through fractures using analytical models.

(3) The effect of localized deformation due to the presence of small scale faults is manifested by the increased non-uniformity in cleat aperture-spacing distribution.

Acknowledgements This is part of KB's doctoral research. This work is also a part of the pilot project for a project proposal (Project No: 154) submitted to The Ministry of Earth Sciences (MoES), Government of India. The authors are grateful to the Indian Institute of Science Education and Research Bhopal (IISERB) for funding the necessary equipment and providing logistical support. We thank Coal India Limited (CIL) for their support and access to coal mines of Raniganj and Barakar coal fields. The authors are also thankful to Prof. S.K.Tandon of the Department of Earth and Environmental Sciences, IISER Bhopal (Grant No. INST/EES/2016037), three anonymous referees and the Editor for their valuable comments that helped immensely to improve the manuscript. The authors have no conflict of interest while publishing this study.

Open Access This article is licensed under a Creative Commons Attribution 4.0 International License, which permits use, sharing, adaptation, distribution and reproduction in any medium or format, as long as you give appropriate credit to the original author(s) and the source, provide a link to the Creative Commons licence, and indicate if changes were made. The images or other third party material in this article are included in the article's Creative Commons licence, unless indicated otherwise in a credit line to the material. If material is not included in the article's Creative Commons licence and your intended use is not permitted by statutory regulation or exceeds the permitted 
use, you will need to obtain permission directly from the copyright holder. To view a copy of this licence, visit http://creativecommons. org/licenses/by/4.0/.

\section{References}

Alzayer Y, Eichhubl P, Laubach SE (2015) Non-linear growth kinematics of opening-mode fractures. J Struct Geol 74:31-44. https://doi.org/10.1016/j.jsg.2015.02.003

Ammosov II, Eremin IV (1963) Fracturing in coal. IZDAT Publishers, Moscow

Apriyani N, Suharmono M, Djaelani S, Sodli A, Satria A, Murtani AS (2014) Integrated cleat analysis and coal quality on CBM exploration at Sangatta II PSC, Kutai Basin, Indonesia. In: AAPG international conference \& exhibition, Istanbul, Turkey, September 14-17

Aydin A, Borja RI, Eichhubl P (2006) Geological and mathematical framework for failure modes in granular rock. J Struct Geol 28:83-98. https://doi.org/10.1016/j.jsg.2005.07.008

Benedicto A, Schultz R, Soliva R (2003) Layer thickness and the shape of faults. Geophys Res Lett 30:2076. https://doi.org/10. 1029/2003g1018237

Boussinesq MJ (1868) Memoire sur l'influence des frottements dans les mouvements reguliers des fluids. J Math Pure Appl 13:377-424

Brook MS, Hebblewhite BW, Mitra R (2016) Cleat aperture-size distributions: a case study from the late Permian Rangal Coal Measures, Bowen Basin, Australia. Int $\mathrm{J}$ Coal Geol 168:186-192. https://doi.org/10.1016/j.coal.2016.11.009

Busse J, de Dreuzy JR, Torres SG, Bringemeier D, Scheuermann A (2017) Image processing based characterization of coal cleat networks. Int J Coal Geol 169:1-21. https://doi.org/10.1016/j. coal.2016.11.01

Campbell JD (1979) Major cleat trends in Alberta Plains coals. CIM Bull 72:69-75

Chakraborty C, Mandal N, Ghosh S (2003) Kinematics of the Gondwana basins of peninsular India. Tectonophysics 377(3):299-324. https://doi.org/10.1016/j.tecto.2003.09.011

Chatterjee R, Paul S (2013) Classification of coal seams for coal bed methane exploitation in central part of Jharia coalfield, India- a statistical approach. Fuel 111:20-29. https://doi.org/10.1016/j. fuel.2013.04.007

Clark RM, Cox SJD (1996) A modern regression approach to determining fault displacement-length relationships. J Struct Geol 18:147-152. https://doi.org/10.1016/S01918141(96)80040-X

Close JC (1993) Natural fractures in coal. In: Law BE, Rice DD (eds) Hydrocarbons from coal. AAPG studies in geology, vol 38. AAPG, Tulsa, pp 119-132

Close JC, Mavor MJ (1991) Influence of coal composition and rank on fracture development in fruitland coal gas reservoirs of San Juan Basin. In: Schwochow SD, Murray DK, Fahy MF (eds) Coalbed methane of western North America. Rocky Mountain Association of Geologists, Denver, pp 109-121

Cowie PA, Scholz CH (1992a) Physical explanation for the displacement-length relationship of faults using a post-yield fracture mechanics model. J Struct Geol 14:1133-1148. https:// doi.org/10.1016/0191-8141(92)90065-5

Cowie PA, Scholz CH (1992b) Displacement-length scaling relationship for faults: data synthesis and discussion. J Struct Geol 14:1149-1156. https://doi.org/10.1016/0191-8141(92)90066-6

Esterle JS, Sliwa R (2002) Bowen Basin Supermodel 2000, ACARP Project C9021, CSIRO Australia Exploration and Mining Report 976C, Brisbane, pp 1-196
Dawson GKW, Esterle JS (2010) Controls on coal cleat spacing. Int J Coal Geol 82:213-218. https://doi.org/10.1016/j.coal.2009.10. 004

Delaney PT, Pollard DD (1981) Deformation of host rocks and flow of magma during growth of minette dikes and breccia-bearing intrusions near Ship Rock, New Mexico, U.S. Geological Survey Professional Paper: 1202

Delaney PT, Pollard DD, Ziony JL, Mckee EH (1986) Field relations between dikes and joints: emplacement processes and paleostress analysis. J Geophys Res 91:4920-4938

Dron RW (1925) Notes on cleat in the Scottish coalfield. Trans Inst Min Eng 70:115-117

Gale JF, Reed RM, Holder J (2007) Natural fractures in the Barnett Shale and their importance for hydraulic fracture treatments. AAPG Bull 91(4):603-622. https://doi.org/10.1306/ 11010606061

Gamson PD, Beamish BB, Johnson DP (1993) Coal microstructure and micropermeability and their effects on natural gas recovery. Fuel 72:87-99

Gudmundsson A (2004) Effects of Young's modulus on fault displacement. C R Geosci 336:85-92. https://doi.org/10.1016/j. crte.2003.09.018

Ghosh SC (2002) The Raniganj Coal Basin: an example of an Indian Gondwana rift. Sediment Geol 147(12):155-176. https://doi.org/ 10.1016/S0037-0738(01)00195-6

Gillespie PA, Howard CB, Walsh JJ, Watterson J (1993) Measurement and characterisation of spatial distributions of fractures. Tectonophysics 226:113-141

Gupta A (2009) Ichthyofauna of the Lower Triassic Panchet Formation, Damodar valley basin, West Bengal, and its implications. Indian Miner 63(3):275-286

Harpalani SS (1999) The compressibility of coal and its impact on gas production from coalbed reservoirs. In: Amadei B, Kranz RL, Scott GA, Smeallie PH (eds) Vail rocks 1999. The 37th US rock mechanics symposium (USRMS), Vail, Colorado, USA rock mechanics for industry. American Rock Mechanics Association, Washington, DC, pp 301-308

Hatton CG, Main IG, Meredith PG (1994) Non-universal scaling of fracture length and opening displacement. Nature 367:160-162

Hooker JN, Gale JFW, Gomez LA, Laubach SE, Marrett R, Reed RM (2009) Aperture-size scaling variations in a low-strain openingmode fracture set, Cozzette Sandstone, Colorado. J Struct Geol 31:707-718. https://doi.org/10.1016/j.jsg.2009.04.001

Hooker JN, Laubach SE, Marrett R (2013) Fracture-aperture sizefrequency, spatial distribution, and growth processes in stratabounded and non-strata-bounded fractures, Cambrian Mesón Group, NW Argentina. J Struct Geol 54:54-71. https://doi.org/ 10.1016/j.jsg.2013.06.011

Kendall PF, Briggs H (1933) XIII-The formation of rock joints and the cleat of coal. Proc R Soc Edinb 53:164-187

Klimczak C, Schultz RA, Parashar R, Reeves DM (2010) Cubic law with aperture-length correlation: implications for network scale fluid flow. Hydrogeol J 18:851-862. https://doi.org/10.1007/ s10040-009-0572-6

Krantz RE, Frankel AD, Engelder T, Scholz CH (1979) The permeability of whole and jointed Barre granite. Int $\mathrm{J}$ Rock Min Sci Geomech Abstr 16:225-234

Kulander BR, Dean SL (1993) Coal-cleat domains and domain boundaries in the Allegheny Plateau of West Virginia. AAPG Bull 77:1374-1388

Laubach SE, Tremain CM (1991) Regional coal fracture patterns and coalbed methane development. In: Roegiers J-C (ed) Proceedings of the 32 nd US symposium on rock mechanics, Balkema, Rotterdam, pp 851-859

Laubach SE, Marrett R, Olson J, Scott AR (1998) Characteristics and origins of coal cleat: a review. Int J Coal Geol 35:175-207 
Laubach SE, Olson J, Gross MR (2009) Mechanical and fracture stratigraphy. AAPG Bull 93(11):1413-1426. https://doi.org/10. 1306/07270909094

Lawn B (1993) Fracture of brittle solids. Cambridge University Press, Cambridge. https://doi.org/10.1017/CBO9780511623127

Li J, Liu D, Yao Y (2011) Evaluation of the reservoir permeability of anthracite coals by geophysical logging data. Int $\mathrm{J}$ Coal Geol 87(2):121-127. https://doi.org/10.1016/j.coal.2011.06.001

Liu Y, Xu H, Tang D, Mathews JP, Zhai Y, Hou W, Li S, Tao S, Xiong X, Wang W (2019) The impact of the coal macrolithotype on reservoir productivity, hydraulic fracture initiation and propagation. Fuel 239:471-483. https://doi.org/10.1016/j.fuel. 2018.10.150

Lomize GM (1961) Water flow in jointed rock (trans. Filtrarsiia v Treshchinovatykh Porod). Gosenergoizdat, Moscow

Louis CA (1969) A study of groundwater flow in jointed rock and its influence of the stability of rock masses. Rock mechanics research report 10. Imperial College, London

Marrett R, Ortega OJ, Kelsey CM (1999) Extent of power-law scaling for natural fractures in rock. Geology 27:799-802

Mauldon M, Dunne WM, Rohrbaugh MB Jr (2001) Circular scanlines and circular windows: new tools for characterizing the geometry of fracture traces. J Struct Geol 23:247-258. https://doi.org/10. 1016/S0191-8141(00)00094-8

Mazumder S, Wolf KHAA, Elewaut K, Ephraim R (2006) Application of X-ray computed tomography for analyzing cleat spacing and cleat aperture in coal samples. Int J Coal Geol 68:205-222

McCulloch CM, Deul M, Jeran PW (1974) Cleat in bituminous coalbeds. In: Mines UBO (ed) Bureau of mines report of investigations. Pittsburgh Mining and Safety Research Center, Pittsburgh, PA

McCulloch CM, Lambert SW, White JR (1976) Determining cleat orientations of deeper coalbeds from overlying coals. US Bur Mines Rep Investig 8116:25

Nicol A, Watterson J, Walsh JJ, Childs C (1996) The shapes, major axis orientations and displacement patterns of fault surfaces. J Struct Geol 18:235-248. https://doi.org/10.1016/S01918141(96)80047-2

Olson JE (2003) Sublinear scaling of fracture aperture versus length: an exception or the rule? J Geophys Res 108(B9):2413. https:// doi.org/10.1029/2001JB000419,2003

Ortega OJ, Marrett RA, Laubach SE (2006) A scale-independent approach to fracture intensity and average spacing measurement. AAPG Bull 90(2):193-208

Oron AP, Berkowitz B (1998) Flow in rock fractures: the local cubic law assumption reexamined. Water Resour Res 34(11):2811-2825

Palmer I (2009) Permeability changes in coal: analytical modeling. Int J Coal Geol 77(1):119-126. https://doi.org/10.1016/j.coal. 2008.09.006

Pattison CI, Fielding CR, McWatters RH, Hamilton LH (1996) Nature and origin of fractures in Permian coals from the Bowen Basin, Queensland, Australia. Geol Soc Lond Special Publ 109(1):133-150. https://doi.org/10.1144/GSL.SP.1996.109.01. 10

Paul S, Chatterjee R (2011) Determination of in situ stress direction from cleat orientation mapping for coal bed methane exploration in south-eastern part of Jharia coalfield, India. Int J Coal Geol 87(2):87-96. https://doi.org/10.1016/j.coal.2011.05.003

Philip ZG, Jennings JW, Olson JE, Laubach SE, Holder J (2005) Modeling coupled fracture-matrix fluid flow in geomechanically simulated fracture networks. Society of Petroleum Engineers, SPE 77340

Pollard DD, Segall P (1987) Theoretical displacement and stresses near fractures in rocks: with applications to faults, joints, veins, dikes, and solution surfaces. In: Atkinson B (ed) Fracture mechanics of rock. Academic Press, London, pp 277-349. https://doi.org/10.1016/b978-0-12-066266-1.50013-2

Prusty BK, Pal SK, Kumar JH (2015) Study of porosity and permeability of coal and coal measure rocks from Raniganj coalfield of India. In: 24th international mining congress and exhibition of Turkey. Abstract volume: 1024

Puri R, Evanoff JC, Brugler ML (1991) Measurement of coal cleat porosity and relative permeability characteristics. In: SPE gas technology symposium, Houston, Texas. Paper 21491, Houston, Texas, pp 93-104

Reid GW, Towler BF, Harris HG (1992) Simulation and economics of coalbed methane production in power river Basin. In: SPE rocky mountain regional meeting. Society of Petroleum Engineers, Richardson, Texas, USA, pp 425-432

Rodrigues CF, Laiginhas C, Fernandes M, Lemos de Sousa MJ, Dinis MAP (2014) The coal cleat system: a new approach to its study. J Rock Mech Geotech Eng 6:208-218. https://doi.org/10.1016/j. jrmge.2014.03.005

Rohrbaugh MB Jr, Dunne Mauldon M (2002) Estimating fracture trace intensity, density, and mean length using circular scan lines and windows. AAPG Bull 86:2089-2104

Sapiie B, Rifiyanto A, Perdana LA (2014) Cleats analysis and CBM potential of the Barito Basin, South Kalimantan, Indonesia. In: AAPG international conference \& exhibition, Istanbul, Turkey, September 14-17

Segall P (1984) Formation and growth of extensional fracture sets. Geol Soc Am Bull 95:454-462

Scholz CH (2002) The mechanics of earthquakes and faulting. Cambridge University Press, Cambridge [ISBN 0-521-652235(hardback)-ISBN 0-521-65540-4(paperback)]

Schultz RA, Okubo CH, Wilkins SJ (2006) Displacement-length scaling relations for faults on the terrestrial planets. J Struct Geol 28:2182-2193. https://doi.org/10.1016/j.jsg.2006.03.034

Schultz RA, Soliva R, Fossen H, Okubo CH, Reeves DM (2008a) Dependence of displacement-length scaling relations for fractures and deformation bands on the volumetric changes across them. J Struct Geol 30:1405-1411. https://doi.org/10.1016/j.jsg. 2008.08.001

Schultz RA, Mège D, Diot H (2008b) Emplacement conditions of igneous dikes in Ethiopian Traps. J Volc Geotherm Res 178(4):683-692. https://doi.org/10.1016/j.jvolgeores.2008.08. 012

Snow DT (1965) A parallel plate model of fractured permeable media. Ph.D. thesis, University of California, Berkeley, USA

Solano-Acosta W, Mastalerz M, Schimmelmann A (2007) Cleats and their relation to geologic lineaments and coalbed methane potential in Pennsylvanian coals in Indiana. Int $\mathrm{J}$ Coal Geol 72:187-208

Soliva R, Benedicto A (2005) Geometry, scaling relation and spacing of vertically restricted normal faults. J Struct Geol 27:317-325. https://doi.org/10.1016/j.jsg.2004.08.010

Sparks DP, McLendon TH, Saulsberry JL, Lambert SW (1995) The effects of stress on coalbed reservoir performance, Black Warrior Basin, USA. In: SPE annual technical conference and exhibition. Society of Petroleum Engineers, Inc Dallas, Texas

Spears DA, Caswell SA (1986) Mineral matter in coals: cleat mineral and their origin in some coals from the English Midlands. Int $\mathbf{J}$ Coal Geol 6:107-125

Ting FTC (1977) Origin and spacing of cleats in coal beds. J Press Vessel Technol 99:624-626

Tremain CM, Laubach SE, Whitehead NH (1991) Coal fracture cleat patterns in Upper Cretaceous Fruitland Formation, San Juan Basin, Colorado and New Mexico: implications for exploration and development. In: Schwochow S, Murray DK, Fahy MF (eds) Coalbed methane of Western North America. Rocky Mountain Association of Geologists, pp 49-59 
Tsang YW, Witherspoon PA (1981) Hydromechanical behavior of a deformable rock fracture subject to normal stress. J Geophys Res 86:9287-9298

Vermilye JM, Scholz CH (1995) Relation between vein length and aperture. J Struct Geol 17:423-434

Vishal V, Singh TN (2015) A laboratory investigation of permeability of coal to supercritical $\mathrm{CO}_{2}$. Geotech Geol Eng 33(4):1009-1016. https://doi.org/10.1007/s10706-015-9882-8

Wilkins SJ, Gross MR (2002) Normal fault growth in layered rocks at Split Mountain, Utah: influence of mechanical stratigraphy on dip linkage, fault restriction and fault scaling. J Struct Geol 24:1413-1429 (erratum, J Struct Geol 24, 2007)

Weniger S, Weniger P, Littke R (2016) Characterizing coal cleats from optical measurements for CBM evaluation. Int J Coal Geol 154-155:176-192. https://doi.org/10.1016/j.coal.2015.12.005

Xu SS, Samaniego NAF, Álvarez SA, Martínez VLG (2005) Effect of sampling and linkage on fault length and length-displacement relationship. Int J Earth Sci 95:841-853

Zhang Y, Gong B, Li J, Li H (2015) Discrete fracture modeling of 3D heterogeneous enhanced coalbed methane recovery with prismatic meshing. Energies 8:6153-6176. https://doi.org/10.3390/ en8066153

Zhi S, Elsworth D, Wang J, Gan Q, Liu S (2018) Hydraulic fracturing for improved nutrient delivery in microbially-enhanced coalbed- methane (MECBM) production. J Nat Gas Sci Eng 60:294-311. https://doi.org/10.1016/j.jngse.2018.10.012

\section{Web reference}

Society of Petroleum Engineers (2017) https://petrowiki.org/Frac ture_mechanics. Accessed 21 May 2019

Shodhganga (2016) https://shodhganga.inflibnet.ac.in/bitstream/ 10603/32892/13/13_chapter\%203.pdf. Accessed 4 Sept 2019

\section{Book reference}

Lawn BR, Wilshaw TR (1975) Fracture of brittle solids. Cambridge Univ Press, New York, pp 204

Williamson IA (1967) Coal mining geology, Oxford University Press, Oxford: 266. ISBN 10:0198599013/ISBN 13: 9780198599012 http://bardhaman.nic.in/mines/mines.htm (2019). 